\title{
Analysis of financial literacy communication strategies in the socialization of the Islamic economy
}

\author{
Barliana Lukitawati ${ }^{1}$, Asep Usman Ismail ${ }^{2}$ \\ \{berliana.lukitawati@uinjkt.ac.id ${ }^{1,}$ asep.usmanuinjkt.ac.id²\} \\ UIN Syarif Hidayatullah Jakarta, Ciputat Tangsel ${ }^{1,2}$
}

\begin{abstract}
Based on the focus of the Financial Services Authority (OJK) in improving financial behavior through educational programs, this study discusses the importance of financial literacy strategies to achieve goals, improve welfare, and avoid financial crises. Especially in facing the Asian economic community (MEA). In addition, the Asian Development Bank also contributes to the creation of a climate of financial literacy in the world community. The purpose of this study is to find a comprehensive picture of the practice of financial literacy communication strategies in the socialization of the Islamic economy. Given that it is not easy to undergo this communication strategy. Research at the Tazkia Institute, with the number of participants in financial literacy programs spread across 20 countries in 2013-2020. The research method used is descriptive method qualitative approach, case study design. The author's data collection technique used literature study, through some literature, interviews, observation and documentation. Analysis techniques: data collection, data reduction, data display, conclusion verification. The result of the research: the communication strategy was carried out with a special financial literacy book that was easy to understand. And interactive teaching to students and the community together. Both online and offline. There is a group of participating alumni that allows for regular guided interaction. So that an understanding of financial literacy is achieved by adjusting the message to the participants. By continuing to market literacy activities to the village. Has a sharia financial Technology (fintech) study centre.
\end{abstract}

Keywords: Financial Literacy, Communication strategy, Islamic economy

\section{Introduction}

Financial problems often complicate human life if humans cannot master their knowledge. At first glance, financial problems seem easy, but often many problems become difficult to solve due to poor management of funds. If you want the best solution, then people must change. Not only habits, but also must be disciplined, honest in managing finances. As in a verse it is said that: 


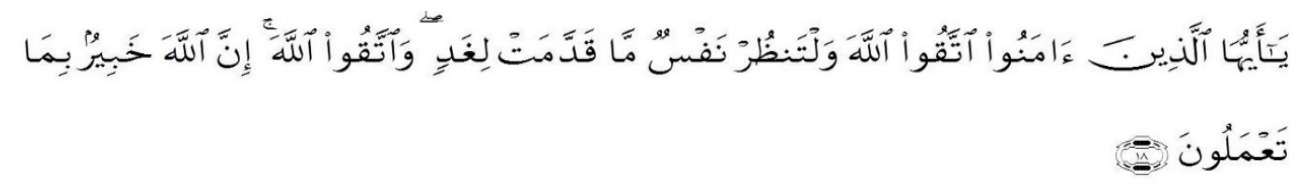

(you who believe, fear Allah and let each one pay attention to what he has done for the next (hereafter); and fear Allah, Allah knows best what you are doing - Surah Al Hashr: 18).

Based on the paragraph above, it is very clear that there is an order that before planning finances, it is necessary to first determine financial goals. Arranging family finances will certainly involve the desires to be achieved. The correct financial arrangement by adhering to Islamic principles will form a calm soul in responding to all financial conditions. So that it gives birth to a quality work ethic because it is based on confidence and serenity. And of course this will have an impact on increasing assets or assets owned.

During life, of course, financial problems will continue to be faced. One of the problems in managing finances is changing habits. Since the economic crisis, consumptive behavior has supported the country's economic growth. Research from The Nielsen company stated that the purchasing power of the Indonesian people was not affected by the global crisis. When juxtaposed with other countries, the level of consumption of the Indonesian people is the third highest in the Asia Pacific. [1]

From this explanation, it can be seen that the main step in financial management is changing habits. Apart from habitual problems, financial problems also include investment. In almost every country there is always an investment that is deceiving the public. In Indonesia it is often referred to as "fake investment". This investment is often successful in attracting his followers. The grandiose promises offered are often successful in luring them to invest. Until then the promise of the expected profit finally disappeared along with the sinking of the funds that had been collected.

Not only that, even those who are not good at managing finances, even though they are not involved in fraudulent investments, also often get into financial problems. Among them are those who are involved in retirement, such as online loans, waste that has an impact on future consequences and damage to one's reputation, as well as mental suffering. So do not be surprised if the Asian Development Bank then took part in providing encouragement for the creation of a climate of financial literacy in the world community.

Among the roles of the Asian Development Bank (ADB) is to collaborate with the OJK (Financial Services Authority) in publishing IT-based books, as a learning module through elearning for universities and students. By emphasizing the younger generation. Where they have responsibility for the future of the nation and state.

Based on the results of the 2016 OJK national financial literacy and inclusion survey, it shows that youth aged 18-35 years have relatively high levels of literacy and financial inclusion 
compared to other age groups nationally, namely a literacy rate of $32.1 \%$ aged $18-25$ years and $33.5 \%$ aged $26-35$ years, and the financial inclusion rate was $70.0 \%$ aged $18-25$ years and $68.4 \%$ aged $26-35$ years.[2]

From this explanation, it can be concluded that the younger generation has a better understanding of financial literacy and inclusion. And this really supports its role as the generation of the nation's hope that will turn the wheels of the economy. So it is not surprising that the Asian Development Bank, through the OJK, emphasizes financial literacy education for the younger generation.

The definition of financial literacy includes The Presidents Advisory Council on Financial Literacy, defines financial literacy: the ability to use knowledge and skills to manage financial resources effectively for a life time of financial well-being. [3] Kim (in Houston, 2010) formulates financial literacy is a basic knowledge that people need in order to survive in a modern society. Thus, the notion of financial literacy can be simplified as knowledge and skills in managing finances as a way to survive in people's lives.[4]

Financial literacy education is provided by the OJK in various ways, such as through elearning through books and other forms such as AKSIMUDA activities, various seminars and other discussion forums. In fact, the OJK collaboration with the Asian Development Bank in developing e-modules has been in place since 2017, especially for young people and students. The use of e learning is an option considering that it is very practical because it is easily accessible via smartphones, tablets and other electronic devices as long as it is connected to the internet. The module can be downloaded in the Sikapi Uangmu minisite (www.sikapiuangmu.ojk.go.id) [5]

From this information, it can be explained that so many communication strategies are used in providing education to the younger generation. Among them is through books. Books are a means of communication that can re-educate the readers according to their wishes. Through this book, interactive interactions occur in the form of questions and answers, in-depth training through advanced trainings, etc. Through e-books, a wide range of readers is also achieved. Some campuses also use strategy through books as a communication strategy. However, some other campuses use a different strategy.

In this study the authors used the Tazkia Institute campus as research subjects. The author takes the campus as a campus that has 2 financial literacy books. At the Tazkia Institute, one of the strategies in financial literacy education is through the Sakinah Finance book, and the 7 income principles book. written by Dr Murniati Manurung with Dr Luqyan Tamanni. Apart from other books too. 


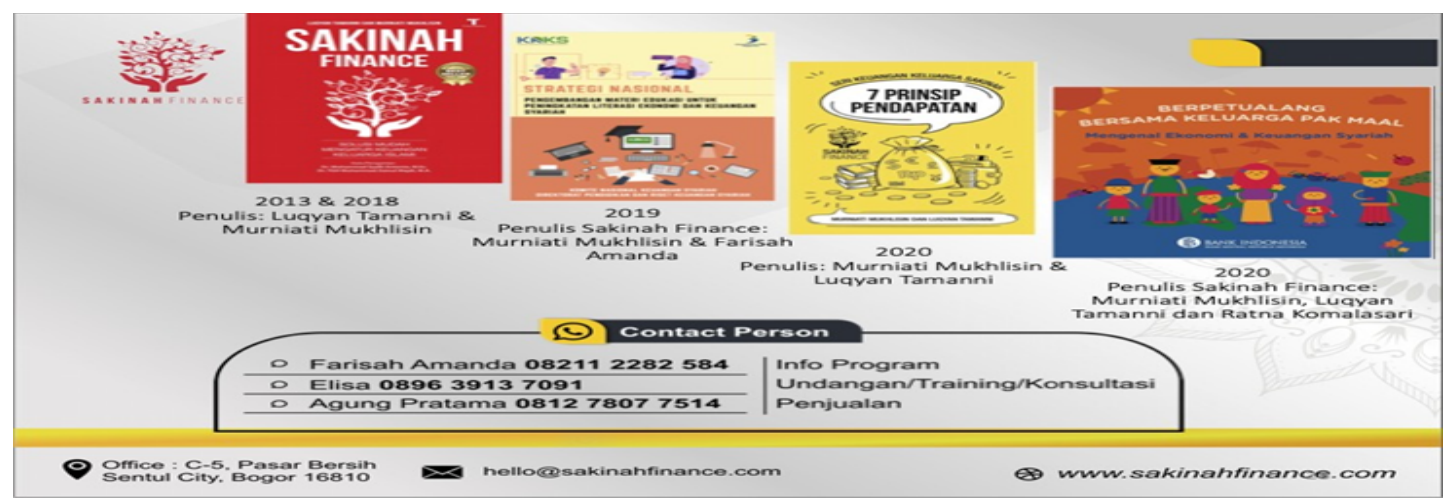

Figure 1 : Tazkia’s Book

Research on communication of Muslim financial literacy on campus is the focus of the author, considering that although the growth of Islamic finance in Indonesia is relatively high, both compared to conventional financial growth and the growth of Islamic finance at the global level, the market share of Islamic finance in Indonesia is still relatively small, namely about 4\%. The market share of Islamic banking has only reached 4.8\% (October 2013). Other Islamic financial institutions, such as insurance are still $2.4 \%$, sharia financing $8.2 \%$, sharia mutual funds 4.9\%, corporate sukuk 3.2\%, State Sukuk (SBSN) 10.3\%. [6]

From this description, it is increasingly clear that the market share of Islamic finance in Indonesia is still small at $4 \%$. So this is where financial literacy communication is needed, especially the younger generation. So for that the authors compile the subject matter. The formulation of the problem is what is the financial literacy communication strategy in the socialization of the Islamic economy?

\section{Literature Review}

In communication activities, there are strategies that are used as references in achieving goals. Communication strategies are important, given that it is not easy to provide financial literacy, especially to the younger generation. Meanwhile, life problems often come from financial problems. Coupled with the temptation to invest in the wrong, with the rise of fictitious investments.

\section{State Of The Art}

In a research by Partono Thomas, Kemal Budi Mulyono, Khasan Setiaji, entitled The Roles of Financial Knowledge, Motivation and Self Efficacy on the Influence of Financial Education toward Financial Literacy aimed to determine the effect of financial education on financial literacy among Economics Faculty students. Meanwhile, the author's research is to find a comprehensive picture of the practice of financial literacy communication strategies in socializing the Islamic economy, as one of the programs of the Financial Services Authority (OJK) and the Asian Development Bank (ADB).[7] 
In the research of Setya Ayu Rahmawati, et all entitled Family Economic Education, Financial Literacy and Financial Inclusion Among University Students In Indonesia. This study aims to determine the level of literacy and financial inclusion of students in several universities in Indonesia. This paper aims to determine the level of literacy and financial inclusion of students and the relationship between family economic education and financial literacy. Whereas the author's research is to find a comprehensive picture of the practice of financial literacy communication strategies, while this previous research examines family economic education with the level of student financial literacy and inclusion in several universities in Indonesia. If the subjects of this research are students at several universities in Indonesia, then in the author's research, the research subjects are executors of financial literacy education at the Tazkia Institute. With the research object is the communication strategy.[8]

In the research of Israel Josedos Santos Felipe et all entitled Investigating The Level of Financial Literacy Of University Students. The purpose of this study was to measure the level of financial literacy of university students in northern Mexico. With the result that the financial attitude of university students in northern Mexico has an effect on their financial behavior. While the author's research is to find a comprehensive picture of the practice of financial literacy communication strategies in the socialization of Islamic economics with research subjects on campus. Given that it is not easy to provide financial literacy education. So a communication strategy is needed. However, knowing the appropriate communication strategy is certainly not easy. So many choices. Here the authors find an overview of the communication strategy practice, which of course still needs to be adjusted to each need. [9]

In the research of I Wayan Nuka Lantara and Ni Ketut Rai Kartini entitled Financial Literacy Among University Students: Empirical Evidence From Indonesia. The purpose of this study was to investigate the level of financial literacy among undergraduate and postgraduate students. This study also examined the relationship between student demographic factors and their level of financial literacy. With research on undergraduate and postgraduate students at Gajah Mada University. [10] Meanwhile, the author's research is to find a comprehensive picture of the practice of financial literacy communication strategies, with research subjects through the Tazkia campus. Meanwhile, I Wayan and Ni Ketut's research examines the relationship between demographic factors of undergraduate and postgraduate students in Indonesia with their level of financial literacy.

In the research of Anastasia Anggarkusuma Arofah; Yunastiti Purwaningsih; Mintasih Indriayu, entitled Financial Literacy, Materialism and Financial Behavior, this research explains that based on the focus of OJK in improving financial behavior through financial education programs, this study discusses the importance of financial literacy and materialism in influencing financial behavior. With the results of the study that financial literacy has a positive and significant contribution to financial behavior. [11]

While the author's research is to find a comprehensive picture of the practice of financial literacy communication strategies, in this case taking research subjects on campus, as one of the programs of the Financial Services Authority (OJK) and the Asian Development Bank (ADB). 
In Suresh Kumar et al's research entitled The Influence of Financial Literacy towards Financial Behavior and its Implication on Financial Decision: A Survey Of President University Students in Cikarang Bekasi $\{20\}$ aimed at finding the effect of financial literacy on financial behavior, and the influence of financial behavior on decision-making. By taking samples of President University students.[12]

While the author's research is to find a comprehensive picture of the practice of financial literacy communication strategies, by emphasizing the stages and important steps in the communication strategy. Given the choice of literacy communication strategies at each campus / institution / individual will certainly vary according to needs.

\section{Research Methodology}

The research method used is descriptive method with a qualitative approach. And with a case study design. While the author's data collection techniques using literature study, through some literature, as well as internet searching, observation and documentation. Data analysis techniques are carried out intensively and continuously, through several steps, namely data collection, data reduction, data display, and conclusion verification.

As for the profile, the Tazkia Institute is a university that was born in the economic crisis of 1997 - 1998. The economic downturn and the collapse of the national banking industry on the one hand and the survival of Islamic banks on the other are milestones in the development of the Islamic economy as a 'system of choice'. STEI Tazkia inaugurates and introduces the first Sharia Fintech study or study center in Indonesia. This Sharia Fintech study center is aimed at examining in depth and thoroughly the development of Fintech in Indonesia, as well as the Center for Halal Studies (PSH), one of which is the development of science around the halal industry and the competence of halal industry players.

Related to this communication strategy, Argenti, Howell, and Beck (2005) said that define strategic communication as "aligned with the company's overall strategy, to enhance its strategic positioning". [13] If linked with this research, it can be said that a literacy communication strategy finance must be in line with the overall campus strategy.

In an article related to communication strategy it is said that First, we examine the emergence of strategic communication as a social phenomenon, how it is applied in today's society, and how it relates to other communication disciplines. [14] If it is related to this research, of course it can be seen how financial literacy communication activities must indeed be related to other communication disciplines, such as financial communication, mass communication psychology, marketing communication and so on as a phenomenon.

According to Harold D. Lasswell, a scientist who is interested in deepening communication. Communication problems involve 5 (five) simple questions as follows: who, says what, to which channels, to whom, with what effect. In simple terms it can be described in the following model:[15] 


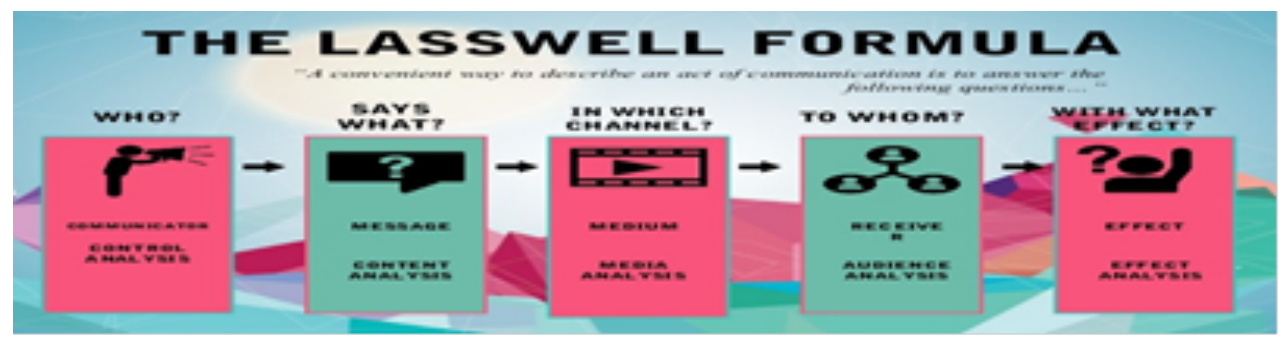

Figure 2 : Laswell Formula

The who refers to who, namely the person who takes the initiative to initiate communication, such as the organization of a union. says what or what is said. The third question is to whom, the meaning of asking who is the audience. The fourth question is in which channel or through what media, such as radio, television, letters, books, pictures, what needs to be considered in this case is that not all media are suitable for certain purposes. The final question from this Lasswell model is what effect or what effect is the communication. This is related to what you want to achieve.

So it can be said that the communication strategy contained in this study includes the elements of communicators, messages, media, recipients and effects. In this research, the communicator here is the campus party that provides literacy education with all its strategies, the message here is the message conveyed through various activities, both books and forums and so on. With a communication channel tailored to the message to achieve the goal or effect in accordance with the expected goals. Both online and offline communication channels. And the message recipients or communicants are students and society. Students are also agents of change who are expected to provide financial literacy education to the public. Given that students have an existence close to society. In addition, the public can directly participate in campus financial literacy through special forums such as online lectures, seminars, webinars and others. The effect in this study is related to the achievement of the goals of family financial literacy communication aimed at students and society.

The communication strategy certainly cannot be separated from the main objective of this strategy. The main objectives according to R. Wayne Pace, Brent D. Peterson and M. Dallas Burnet in Effendi are as follows: a. To secure understanding, the meaning here is to provide certainty that the message has reached the communicant and is understood. b. To establish acceptance, then after the communicant understands the message is to provide guidance to the communicant. c. to motivate action, the next step is to motivate the communicant. [16]

If it is related to research, the "to secure" message is conveyed to the public and students in simple and understandable language. By providing examples and explanations that are repeated. Regarding "to establish acceptance," further guidance is carried out by repeating material through theoretical and practical studies such as seminars, webinars, YouTube videos, regular monthly lectures with studies on important topics or financial issues, and so on. And for "to motivate action", it is done by continuously providing information on activities, participant testimonials, and providing motivational quotes on several social media. 
According to Arifin, so that messages can be conveyed effectively, it is necessary to determine the steps for a communication strategy as follows:

\section{Know the Audience}

Audience recognition can be done by observation, exploration, or research. Knowing the audience should be the first step for the communicator in effective communication efforts. This can be done by conducting visits, seminars or open discussions. Knowing the audience is a very important process because they will receive new ideas. By knowing the audience, it is easier to move on to the next process.

\section{Compose the Message}

Compiling a message is defined as compiling a material theme. The main requirement in influencing the audience from the message is that it is able to arouse the audience's attention. The composition of messages in this study is to determine whether there is material planning before the subject makes a promotion of the product to be promoted. Furthermore, to find out how the subject arouses the attention of potential buyers through the contents of the message.

\section{Setting Mode}

In setting the mode, it can be realized in the form of redundancy and canalizing. Redundancy is a way of influencing audiences by repeated messages. And canalizing, namely communicators try to understand what kind of communication frame of reference and the field of audience experience. Then formulate messages and methods according to this. In redundancy, the subject influences prospective buyers by posting promotion, for example by giving discounts on every item or receiving giveaways such as prizes. While canalizing, the subject tries to understand potential buyers as seen from the responses of consumers in the form of testimonials. So that the subject can determine and create messages and methods according to this.

\section{Selection of media usage}

As in composing the message of a communication to be carried out, we must be selective in the sense of adapting to the circumstances and conditions of the audience, so naturally in using media it must be this way. This is because each medium has its own capabilities and weaknesses as a tool.

From the explanation above, it is very clear that the campus is implementing a communication strategy involving the 4 elements to be analyzed. As well as several related things. If associated with this research, then:

1. Know the audience, in this case the Tazkia Institute provides literacy education to students and the public directly. People who take part in this literacy education generally come from people who are familiar with the campus environment such as the surrounding community, campus extended families, campus taklim congregations, and people outside the campus environment who have the desire to study family financial literacy. They departed from the same interest, namely studying financial literacy. 
2. Compiling messages, in this case the delivery of material is done through writing (text) or oral. In writing through text books, orally at seminars, webinars, and others. In addition to messages that are arranged through regular monthly lectures that discuss important topics and financial issues, as well as other meeting forums. The message is conveyed in simple language that is easy to understand, both by the general public and students. The delivery of messages is repeated and accompanied by dialogue and questions and answers. Provide a lively and intimate atmosphere between the communicator and the audience.

On several campuses there are those that emphasize financial literacy education to students, then students as agents of change who have a close existence with the community carry out community service by providing financial literacy education to the community through messages that are simple and easy to understand.

3. Setting the Mode, in this study the arrangement of messages both textually and orally is packaged and arranged in a form that has been adjusted to the frame of reference and experiences of students and society. In redundancy, the delivery is repeated routinely. By canalizing, the campus delivers to students according to the frame of reference and the field of student experience in the field of financial literacy. And repeated regularly in interactive dialogue, question and answer. Either through new topics or old topics.

4. Selection of media use, considering that each media has its own advantages and disadvantages. For various activities and information for students, Instagram, Facebook, website, twitter, youtube, and other social media can be accessed by all students and the public. This includes the delivery of printed books. Both the message content contains knowledge, as well as information and promotions. So that online media is able to reach quite a wide readership. Apart from that, offline media are also used, such as banners, brochures, and others.

Furthermore, in the education system it is said that "The method is the realization of the theory which includes the selection of systematic techniques based on special abilities, content or material taught and activities in the delivery of material." [17] In this case, there is a systematic technique based on specific abilities for the delivery of content and activities carried out by the campus. So that financial literacy communication becomes complete.

As for activities in communication as one of the communication strategies, Kirk Halllahan stated that although their specific activities can be conceptualized in various ways - from coordinating administrative functions to product promotion and relationship building — all of these disciplines involve the organization, defined in its broadest sense., communicating purposefully to advance its mission. This is the essence of strategic communication. [18] Thus, if it is related to this research, the Tazkia campus uses various financial literacy communication techniques such as webinars, taklim activities, seminars, videos, Instagram, Facebook, YouTube and others in its communication strategy. Besides also building continuous interactive relationships to achieve financial literacy communication goals.

Regarding the use of media, Mc Quail said that the functions of the media include: information, correlation, continuity, entertainment and mobilization. [19] If it is related to this research, the online and offline media also function as a means to build closeness through 
continuous coaching as well as providing information and motivation. Given the different functions of media, Tazkia adapts to needs. In this case Tazkia uses print, electronic and cyber mass media

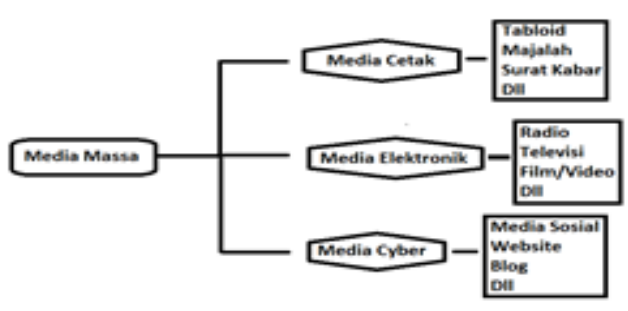

Figure 3: The use of media by Mc Quail's model

In this financial literacy communication Leon Schiffman said that learning is the process by which individuals acquare the purchase and consumption knowledge and experience that they apply to future related behavior. Several points in this definition are worth noting. [20] If it is related to this research, the coaching of the learning process is continuously carried out both through advanced training and through online and offline mass media. Remembering that learning requires a process, so in its communication strategy Tazkia carries out continuous coaching. 


\section{Framework}

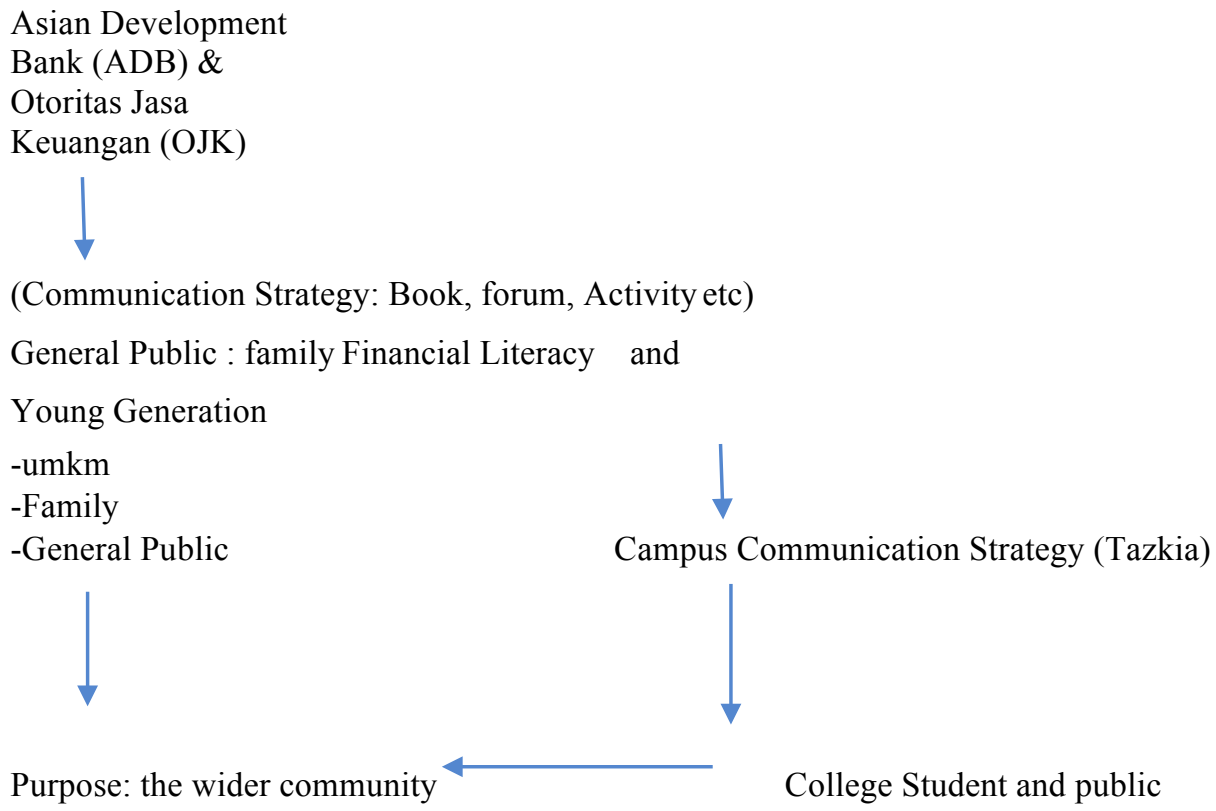

Figure 4. Overview of Research Thinking Framewor

\section{Research Result}

From the discussion in the above theories, it is found that the Tazkia Institute has implemented 4 elements of a communication strategy, including getting to know audiences who generally come from students and campus communities such as jamaah taklim, the Tazkia extended family, or from other parties who have the same goal, namely learning literacy. Family finance. As well as composing messages in easy-to-understand language adapting to a diverse environment of financial knowledge and experience. Communication is carried out repeatedly so that it can be understood, with the presence of a participant alumni group so that they are continuously fostered by strategies for using online and offline media that are tailored to their needs. Be it Instagram, Facebook, website, youtube, twitter, banners, brochures and so on.

Another strategy besides forums is the financial literacy books. Currently Tazkia has a book on finance sakinah and 7 income principles. Apart from that, it also motivates participants to achieve this program. In this literacy communication, both students and the community participate in the training together. These trainings include retirement planning, practice 7 income principles, managing Islamic finance during a pandemic, Islamic financial planning. In addition there are online lectures such as the importance of managing finances for Muslim families, reaching a safe family through financial management, seven principles of Muslim family financial management, writing financial reports, managing surpluses and deficits, 
managing contingency and vacation planning and so on. Besides that, there is also further material on the calculation of zakat, sharia pensioners and so on. The following are some financial literacy materials for students and the general public.

\begin{tabular}{l|ll}
\hline \multicolumn{1}{|c}{ Kelas Dasar (10 Modul) } & Kelas Lanjutan (8 Modul) & \multicolumn{1}{c}{ Tahapan Kuliah Online } \\
\hline Keuangan Sakinah; & Inovasi Bisnis; & 1. Peserta memilih tema \\
7 Prinsip Pendapatan; & Akad Bisnis Syariah; & 2. Pendaftaran melalui google Form \\
Praktik Penulisan; & Zakat; & 3. Transfer Biaya dan Konfirmasi \\
Kebutuhan, Impian; & Hutang; & 4. Mempelajari video materi dan \\
Surplus dan Defisit, & Pernikahan; & meyiapkan Pertanyaan \\
Ketidakpastian, Edukasi & Bisnis Syariah untuk Anak; & 5. Diskusi real time \\
Keuangan & Pensiun; & 6. Mendapatkan e-certificate \\
& Waris &
\end{tabular}

Figure 5: Tazkia’s Program in Financial literacy

Until now, there have been 20 participating countries in the world from 2013 to 2020 . The total as of May $2020=15,230$ participants and 193 trainers, more than 20 countries. Meanwhile, during the pandemic there were 3275 participants from 10 countries. [21]

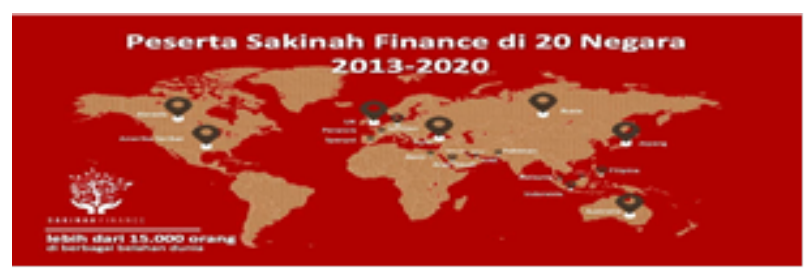

Figure 6: Participants in 20 countries

\section{Conclusion and suggestion}

In financial literacy communication, strategies are needed to achieve goals. This process is carried out continuously through books and forums. By using online and offline media. With messages tailored to the understanding of participants and interesting. Continuous coaching is needed in communicating financial literacy. The Tazkia Campus uses initial and advanced materials, as well as other forums. Supported by a variety of communication channels. As Well as marketing using online and offline media. By continuing to market literacy activities to the village.

Education is carried out jointly between students and the community. Even the participants also came from several other countries. Communication strategy is not enough just through books, but it is necessary together to create a comfortable and continuous learning atmosphere. The use of communication channels is tailored to the needs. Similarly, the message is to achieve the objectives of financial literacy communication. And provide the facilities needed to achieve the strategy, for example in financial literacy in cooperation or having a sharia fintech study center. Suggestion, students need to be emphasized as agents, because they have a close existence with the community, as well as being the successor of the 
nation's economic generation. So now the role of students or the younger generation can be involved as conveying literacy messages to further improve effective communication strategies. In this study, students still lacked their role as agent of change.

\section{Acknowledgments}

Acknowledgments are given to all parties who helped carry out this research to completion

\section{Reference}

[1] M. Bagus, Perencanaan Keuangan. Jakarta: Erlangga, 2010.

[2] F. Sulaiman, "Ojk Luncurkan buku e learning literasi keuangan untuk SD dan SMP," Warta Ekonomi.co.id, Jakarta, p. 4, 2018.

[3] S. Houston, "Measuring Financial Literacy. The Journal of Consumer Affairs.," timesreader, 2010. [Online]. Available: http nnnnn.

[4] Hung et all, Defining and Measuring Financial Literacy. Solo: Erlangga, 2009.

[5] S. Nina, OJK bikin AKSIMUDA 2019 demi giatkan literasi keuangan. Semarang: Tiga serangkai, 2019.

[6] A. Tianto, "Membangun Literasi keuangan syariah,” Iqtishadconsulting.com., Jakarta, p. 12, 2015.

[7] Partono et all, "The Roles of financial knowledge, motivation and self efficacy on the influence of financial education towaard financial literacy," 2016.

[8] Rahmawati et all, "Family Economic Education, Financial Literacy and Financial Inclusion Among University Students In Indonesia," 2019.

[9] J. Israel, "Investigating The Level of Financial Literacy Of University Students," 2017.

[10] I Wayan Nuka Lantara and Ni KetutRai Kartini, "Financial Literacy Among University Students: Empirical Evidence From Indonesia.” Erlangga, Solo, p. 2015, 2019.

[11] Anastasia et all, "Financial literacy, materalism and financial behavor," Kompasiana, vol. 12, p. 12, 2018.

[12] Kumar Suresh et all, "The Influence of Financial Literacy towards Financial Behavior and its Implication on Financial Decision: A Survey Of President University Students in Cikarang Bekasi." 2017.

[13] Argenti et all, "The strategic communication imperative. MIT Sloan Management Review," kompasiana januari, 2005. [Online]. Available: www.ompasanammmmm.

[14] Halallan et all, "International Journal of Strategic Communication Publication." 2007.

[15] H. Laswell, "The structur and function of communication in society." Light Publisher, London, p. $27,1948$.

[16] O. Efendi, "Ilmu, Teori dan filsafat Komunikasi,.” Raja Grafindo, Jakarta, p. 38, 2013.

[17] S. Darnis, "The Influence of Communicative Method and Independent Learning Style to the English Learning Outcomes: An Experiment Research to Primary Grade One Level. International Journal of Linguistics, Literature and Translation,.” 2020.

[18] Kirk Hallahan et all, "Defining strategic Communication. an International Journal of Strategic Communication." p. 121, 2010.

[19] Mc Quail, "Mass communication theory." London, p. 90, 2018.

[20] Leon G. stuartet all, Consumer Behavior. Pearson,. New Jersey, 2011.

[21] “Tazkia’s Instagram.” Institut Tazkia, Bogor, 2020. 